\title{
Genetic Analysis of Yield and Its Attributes in Wheat (Triticum aestivum L.) Under Normal Irrigation and Drought Stress Conditions
}

Naglaa Qabil ${ }^{\#}$

Agronomy Department, Faculty of Agriculture, Zagazig University, Zagazig, Egypt.

\begin{abstract}
CLIMATE change and global warming cause an increase of drought effects on wheat production all over the world. Therefore developing wheat drought tolerant genotypes is essential, especially, under current water shortage. The present study was performed at the Experimental Farm, Faculty of Agriculture, Zagazig University, Egypt over winter seasons 2014/2015 and 2015/2016. Five diverse parental wheat genotypes (Misr 1, Gemmeiza 9, Gemmeiza 11, Line 1 and Line 2) were involved in a half diallel cross fashion under normal irrigation and drought stress conditions to investigate the effect of drought stress on yield and related contributing traits through mean performance, combining ability and gene action. The results showed significant differences among parental wheat genotypes and their $F_{1}$ crosses as well as highly significant mean squares of general and specific combining ability for all studied traits under both conditions. For days to heading, Line 1 exhibited good level of earliness reflected in the performance of their $F_{1}$ crosses (Line 1 x Misr 1) and (Line $1 \mathrm{x}$ Line 2) under both conditions. The local wheat cultivars Misr 1 and Gemmeiza 9 as well as their $\mathrm{F}_{1}$ cross (Misr $1 \mathrm{X}$ Gemmeiza 9) had high mean values for yield and its components under both conditions, reinforcing their importance in applied breeding programs. The parental wheat cultivar Gemmeiza 11 and $F_{1}$ crosses (Line 1 x Gemmeiza 11), (Misr 1 x Line 2) and (Gemmeiza 9 x Gemmeiza 11) showed drought sensitivity index (DSI) values less than unity. Thus, these genotypes were considered as more tolerant to drought stress as regards to their grain yield/plant. The magnitude of additive (D) genetic component was higher as compared to their corresponding dominance $\left(\mathrm{H}_{1}\right.$ and $\left.\mathrm{H}_{2}\right)$ ones, for days to heading both conditions and number of grains/spike under drought stress one, resulting $\left(\mathrm{H}_{1} / \mathrm{D}\right)^{0.5}$ less than unity. While, the dominance components was more than the corresponding additive one for flag leaf area, chlorophyll content, number of spikelets/spike, spike length, spike density, number of spikes/ plant, 1000-grain weight and grain yield /plant under both conditions as well as number of grains/spike under normal irrigation only. The average degree of dominance was more than unity, confirming the importance of over-dominance in the genetic of these traits. under both conditions, the regression lines cut Wr axis above point of origin for days to heading, showing that partial dominance mode of inheritance for this character through additive gene action. On the other hand, it cuts $\mathrm{Wr}$ axis below origin for grain yield/plant, demonstrating that overdominance gene effects are the prevailed type.
\end{abstract}

Keywords: Bread wheat, Diallel, Drought stress, Combining ability, Gene action.

\section{Introduction}

Wheat is the most important grain crop in Egypt as a source of human food. Egypt's total wheat production of grain reached about 9 million tons resulted from 3.4 million faddens with 2.65 ton/ faddan, while the consumption of wheat grains is about 15 million tons (Anonymous, 2016). Decreasing the gap between wheat production and consumption is a national aim of Egypt.
This gap could be limited through increasing production per unit area by breeding new varieties with high yielding ability and increasing the cultivated area. But the limiting of increasing the cultivated area in Egypt is the availability of irrigation water. Prospect increasing of wheat area is possible only in the Egyptian desert. But, this area is sandy soil with low water catching ability and thus wheat plants expose to water

"Corresponding author email: naglaaqabil82@yahoo.com

DOI : 10.21608 /agro.2017.1388.1069

C2017 National Information and Documentation Center (NIDOC) 
stress. Such water stress causes great decreases in yield. So improvement tolerance to drought stress through hybridization is one of the most important breeding objectives in wheat, which causes increasing of productivity under drought stress conditions.

Combining ability analysis of Griffing (1956) is most widely used as biometrical tool for determining parental lines from where their ability to combine in hybrids. With this method, genetic variation is divided into general combining ability variance, a measure of additive gene action and specific combining ability variance, as a measure of dominance one.

Diallel analysis procedure as out lined by Hayman (1954 a and b) and Mather \& Jinks (1971) was used to estimate the relative magnitude of the genetic components of variance to obtain information on the genetic mechanisms of the studied characters. Golparvar et al. (2011), Saleh (2011) and Salehi et al. (2014) found that the way of gene action and assessment of genetic parameters are varied for the characters under normal irrigation and drought stress conditions and for this reason presented different breeding strategies for developing each of evaluating under two environments. The additive gene effects were the main component in the genetic of days to heading, suggesting that the fixable gene type could be exploited efficiently through phenotypic selection in the early generation (Akram et al., 2008; El-Moselhy, 2009 and Abdallah et al., 2015). While, additive and dominant gene effects were involved in the genetic of grain yield via more attributions to over-dominance effects (Badieh et al., 2012). The dominance component was more than the corresponding additive one for grain yield (Al-Naggar et al., 2007; Ahmed \& Mohamed, 2009, El-Moselhy, 2009; Sedek, 2009 and Abdallah et al., 2015).

In the present study an attempt was made to determine the genetic behavior and combining ability effects for heading, yield and its components in a set of five wheat parents diallel analysis under both normal irrigation and drought stress conditions.

\section{Materials and Methods}

The field experiments of this work were performed at the Experimental Farm of the Faculty of Agriculture, Zagazig University, during the successive growing seasons 2014/2015 and 2015/2016. Five diverse parental wheat genotypes (Misr 1, Gemmeiza 9, Gemmeiza 11, Line 1 and Line 2) were involved in half diallel cross fashion, excluding reciprocals. The parents used were chosen on the basis of the presence of wide differences among them with respect to days to heading, yield and its attributes. The pedigree and origin of the wheat parental genotypes are presented in Table 1.

TABLE 1. Pedigree and origin of the wheat parental genotypes.

\begin{tabular}{cclr}
\hline No. & Genotypes & \multicolumn{1}{c}{ Pedigree } & Origin \\
\hline 1 & Misr 1 & OASIS/KAUZ//4*PASTOR.CMss00Y01881T-050M-030Y-030M-030WGY-33M- & Egypt \\
2 & Gemmeiza 9 & ALD “S” HUAC "S”// CMH74A.630/5XCGM4583-5GM-1GM 0GM & Egypt \\
3 & Gemmeiza 11 & BOW"s"/KVZ/ 7C/SERI82/3/GIZA168/SAKHA61 & Egypt \\
4 & Line1 & Sakha 93/Sids6 CGZ(16)GM-2GM-OGM & Egypt \\
5 & Line2 & Giza 168/Sids7 CGZ(7)4GM-2GM.OGM & Egypt \\
\hline
\end{tabular}

In 2014/2015 season, all possible cross combinations, excluding reciprocals were made between these parents to produce $10 \mathrm{~F} 1$ crosses. Hence, in 2015/2016 season the 5 parents and their $10 \mathrm{~F} 1$ crosses were sown in a randomized complete block design (RCBD) with three replications under normal irrigation and drought stress conditions. Sowing date was 21 November in both seasons, which is considered within the optimal period for wheat cultivation in the area. In all experiments, the experimental plot consist of 7 rows (three for each parent of each cross and one for their F1). The row was $2 \mathrm{~m}$ long inter row and inter plant distances were kept at $20 \mathrm{~cm}$ and $10 \mathrm{~cm}$, respectively. Under normal irrigation treatment, plots were irrigated four times after sowing. The four irrigations were done at tillering, jointing, flowering and grain filling stages, in total $2000 \mathrm{~m}^{3} / \mathrm{fad}$. While, under drought stress treatment, irrigation was prevented after tillering stage up to maturity in total once irrigation after sowing with $600 \mathrm{~m}^{3} / \mathrm{fad}$. The soil 
of the experimental fields were clay in texture, physical and chemical analysis are presented in Table 2. Average of minimum and maximum

TABLE 2. Soil properties of the experimental site at $30 \mathrm{~cm}$ soil depth in the both seasons. temperatures and total rainfall during growing seasons are presented in Table 3.

\begin{tabular}{lc}
\hline Properties & Value \\
\hline Sand\% & 20.61 \\
$\mathrm{Silt} \%$ & 31.82 \\
$\mathrm{Clay} \%$ & 47.57 \\
Textural class & Clay \\
$\mathrm{CaCO} 3\left(\mathrm{~g} \mathrm{~kg}^{-1}\right)$ & 6.14 \\
$\mathrm{Organic} \mathrm{matter}\left(\mathrm{g} \mathrm{kg}^{-1}\right)$ & 10.34 \\
$\mathrm{pH}$ & 8.02 \\
$\mathrm{EC}\left(\mathrm{dSm}{ }^{-1}\right)$ & 1.94 \\
$\mathrm{Ca}^{++}$ & 5.22 \\
$\mathrm{Mg}^{++}$ & 4.37 \\
$\mathrm{Na}^{+}$ & 4.52 \\
$\mathrm{~K}^{+}$ & 5.39 \\
$\mathrm{HCO}^{-}$ & 6.08 \\
$\mathrm{Cl}^{-}$ & 6.58 \\
$\mathrm{SO}^{=}$ & $\mathrm{N}$ \\
$\mathrm{P}$ & 6.84 \\
$\mathrm{~K}^{-}$ & 57.32 \\
\hline
\end{tabular}

Central Laboratory of Faculty of Agriculture, Zagazig University, Zagazig Egypt.

TABLE 3. Average of minimum and maximum temperatures and total rainfall during growing seasons in the experimental site.

\begin{tabular}{lcccccc}
\hline & \multicolumn{2}{c}{$\mathbf{2 0 1 4 - 2 0 1 5}$} & \multicolumn{2}{c}{$\mathbf{2 0 1 5 - 2 0 1 6}$} \\
\cline { 2 - 7 } & Tmin & Tmax & Rain (mm) & Tmin & Tmax & Rain (mm) \\
\hline November & 13.3 & 25.3 & 8.5 & 14.4 & 26.1 & 6.4 \\
December & 10.3 & 22.7 & 11 & 9.6 & 20.6 & 12.2 \\
January & 7.1 & 18.9 & 12.7 & 6.8 & 18.2 & 11.3 \\
February & 7.7 & 20.3 & 13.2 & 9.2 & 24 & 15.5 \\
March & 10.2 & 25.5 & 8.6 & 10.3 & 26.2 & 10.7 \\
April & 11.7 & 28.5 & 6.1 & 13.1 & 33.1 & 3.6 \\
May & 16.7 & 34.1 & 1.8 & 17.3 & 34.5 & 1.2 \\
\hline
\end{tabular}


Ten competitive plants were taken randomly from each of the parental genotypes and their F1's and labeled to collect data for days to heading, flag leaf area $\left(\mathrm{cm}^{2}\right)$, chlorophyll content (\%), number of spikelets/spike, spike length $(\mathrm{cm})$, spike density, number of spikes/plant, number of grains/spike, 1000-grain weight (g.) and grain yield/ plant (g.).

Analysis of variance was conducted as outlined by Steel et al. (1997) for all the characters. Estimation of both general (GCA) and specific (SCA) combining abilities were computed according to Griffing (1956) designated as method 2, model 1 for the studied traits. Diallel analysis procedure, as outlined by Hayman (1954 a and b) and Mather \& Jinks (1971) was used to estimate the relative magnitude of the genetic components of variance (D, $\mathrm{H}_{1}, \mathrm{H}_{2}, \mathrm{~h}^{2}, \mathrm{~F}$ and $\left.\mathrm{E}\right)$ to obtain information on the genetic mechanisms of the studied characters. The derived parameters were also calculated from the following equations:

(a) $\left(\mathrm{H}_{1} / \mathrm{D}\right)^{0.5}$ : The average degree of dominance.

(b) $\left(\mathrm{H}_{2} / 4 \mathrm{H}_{1}\right)$ : Refer to the proportion of genes with positive and negative effects in the genetic constitution of parental genotypes.

(c) $\mathrm{KD} / \mathrm{KR}=\left(4 \mathrm{DH}_{1}\right)^{0.5}+\mathrm{F} /\left(4 \mathrm{DH}_{1}\right)^{0.5}-\mathrm{F}$.

This ratio refers to the proportion of dominance and recessive genes in the studied parents.

Heritability in narrow $\left(T_{n}\right)$ sense was calculated according to Mather \& Jinks (1982) using the following equation:

$T_{(n)}=\frac{\frac{1}{2} D+\frac{1}{2} H_{1}-\frac{1}{2} H_{2}-\frac{1}{2} F}{\frac{1}{2} D+\frac{1}{2} H_{1}-\frac{1}{4} H_{2}-\frac{1}{2} F+E}$

The covariance $\left(\mathrm{W}_{\mathrm{r}}\right)$ between the parents and off spring was plotted against the variance $\left(\mathrm{V}_{\mathrm{r}}\right)$ of one array (one cultivar and all crosses involving it considered) construct the $\mathrm{W}_{r} / \mathrm{V}_{\mathrm{r}}$ graph according to Hayman (1954 a and b) and Jinks (1954).

Drought sensitivity index (DSI) was used as a measure of drought stress tolerance in terms of minimization of the reduction in grain yield caused by unfavorable versus favorable environments. (DSI) was calculated for each genotype according to the formula of Fischer \& Maurer (1978):

$$
\mathrm{DSI}=\left(1-\mathrm{Y}_{\mathrm{S}} / \mathrm{Y}_{\mathrm{P}}\right) / 1-\left(\mathrm{X}_{\mathrm{S}} / \mathrm{X}_{\mathrm{P}}\right)
$$

where:

$\mathrm{Y}_{\mathrm{S}}=$ Mean of grain yield of a genotype under drought stress condition.
$\mathrm{Y}_{\mathrm{P}}=$ Mean of grain yield of a genotype under normal irrigation condition.

$\mathrm{X}_{\mathrm{S}}=$ Mean of all genotypes under drought stress condition.

$\mathrm{X}_{\mathrm{p}}=$ Mean of all genotypes under normal irrigation condition.

\section{Results and Discussion}

Analysis of variance

The analysis of variance showed significant differences among genotypes, parents and their $F_{1}$ crosses for all studied traits under both conditions (Table 4), revealing the presence of adequate genetic variability. In this respect, significant differences among wheat genotypes were recorded for days to heading, flag leaf area, spike length, number of spikes/plant, number of grains/spike, 1000-grain weight and grain yield per plant under normal irrigation and drought stress conditions by Parchin et al. (2011), Saleh (2011), Tsegaye et al. (2012) and Swelam et al.(2014). Also, Muhammad- Uzair et al. (2016) reported high degree of genetic variability between wheat genotypes in respect to number of spikelets/spike, spike length, number of grains/spike, 1000-grain weight and grain yield per plant under drought stress condition.

Highly significant mean squares due to general combining ability (GCA) and specific combining one (SCA) were detected for all characters under both conditions (Table 4), suggesting the importance of both additive and dominance effects in expression of all these characters. The ratio of GCA/SCA variance was more than unity for most characters under two conditions, indicating the major role of additive gene action in the inheritance of these characters. While, ratio of $\mathrm{GCA} / \mathrm{SCA}$ variance was less than unity for chlorophyll content under drought stress condition, reinforcing the importance of dominance gene action in governing chlorophyll content under drought stress condition, hereby hybrid breeding method could be used for improving this trait. Also, GCA/SCA ratio was near to unity for grain yield/plant under normal irrigation and drought stress conditions, revealing complete dominance mode of inheritance. It was reported that the mean squares due to GCA were much higher in magnitude than those of SCA for days to heading, flag leaf area, spike length, number of spikes/plant, number of grains/spike and 1000- grain weight (Hamada \& El-Beially, 2003; Inamullah et al., 2006; AL-Naggar et al., 2007; EL- Shamarka et al., 2009; El-Moselhy, 2009 and Abdallah et al., 2015). Otherwise, El-Moselhy (2009) and EL-Shamarka et al. (2009) reported that the GCA/SCA ratio was near to unity for grain yield/plant. 

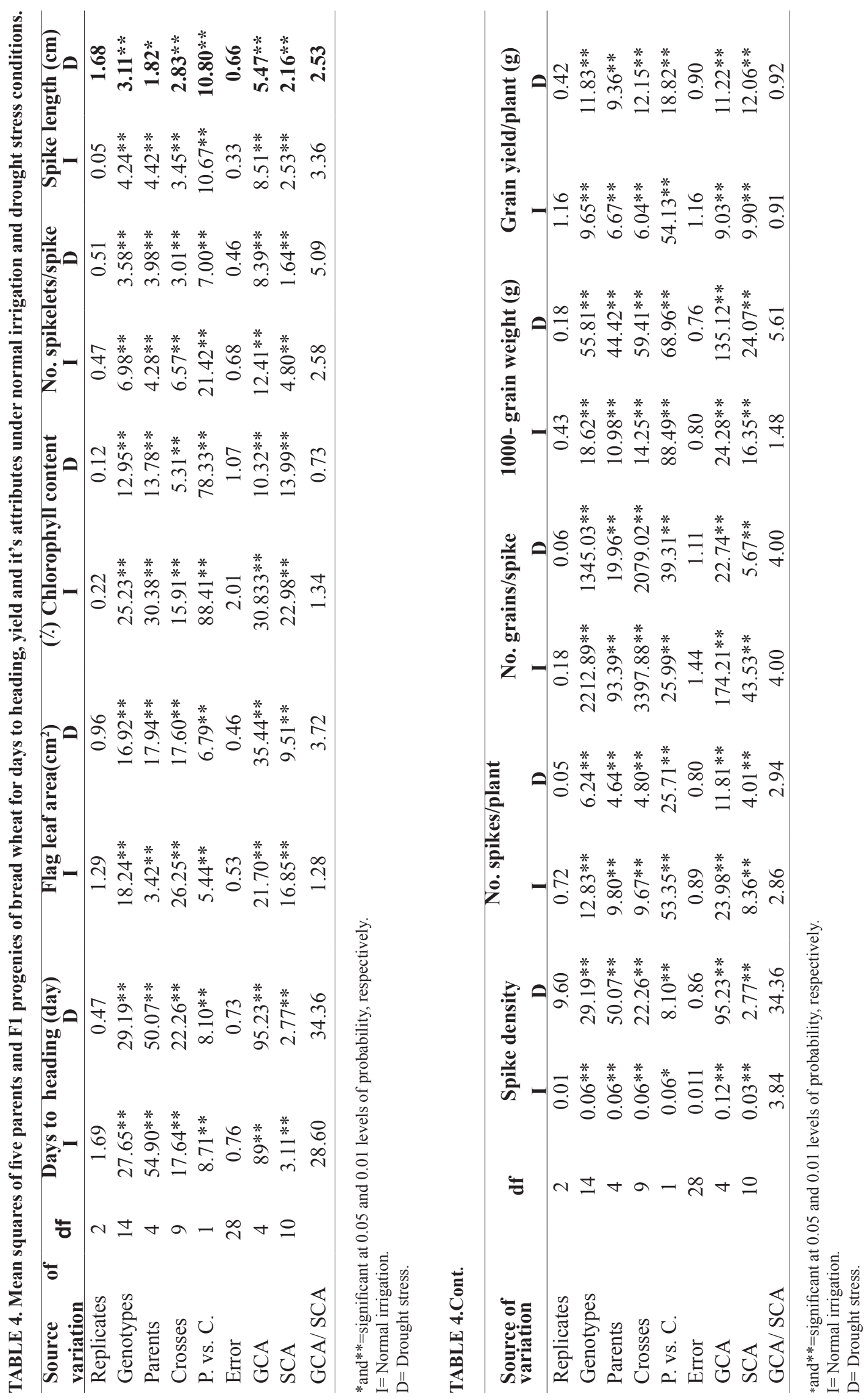

Egypt. J. Agron. Vol. 39, No.3 (2017) 


\section{Mean performance}

Mean performance of the studied characters for parental wheat genotypes and their $F_{1}$ crosses under conditions are shown in Table 5.

Generally, under normal irrigation (favorable) the studied characters showed an increase when compared with drought stress. This result may be due to that drought stress restricted the production of wheat grain yield and contributing characters. In this connection, similar results were recorded by Bindraban et al. (1998), Khamssi (2012) and Swelam et al. (2014).

Mean performance of parental genotypes and their $F_{1}$ crosses regarding days to heading indicated that the exotic one Line 1 was the earliest ones under both conditions. The good level of earliness pronounced in Line 1 was reflected in the performance of their $F_{1}$ crosses (Line 1 x Misr 1) and (Line 1 x Line 2) under both conditions. While, the local wheat genotype Gemmeiza 9 was the latest as well as their $\mathrm{F}_{1}$ crosses (Gemmeiza 9 x Gemmeiza 11), (Line 2x Gemmeiza 9) and (Misr $1 \mathrm{x}$ Gemmeiza 9) under both conditions. These results suggest that genes controlling early heading have been transferred from the parents to their $F_{1}$ progeny. Therefore, these genotypes were promising ones for early heading.

Mean performance of flag leaf area indicated that local wheat cultivar Gemmeiza 9 as well as their $F_{1}$ crosses (Misr 1 x Gemmeiza 9) and (Gemmeiza 9 x Gemmeiza 11) under both conditions as well as (Line 1 x Gemmeiz 9) under normal irrigation have broader flag leaf area. Therefore, these genotypes could be used for selecting new recombinants characterized by broader flag leaf area.

Concerning chlorophyll content (Table 5) showed that the local wheat cultivar Gemmeiza 11 and their respective cross (Line $1 \times$ Gemmeiza 11) had high mean values under both conditions, reinforcing their importance in applied breeding programs.

The greatest number of spikelets/spike have been registered by the local wheat cultivars Gemmeiza 9 and Gemmeiza 11 under both environments as well as their $\mathrm{F}_{1}$ crosses (Misr 1 x Gemmeiza 9) under normal irrigation and (Gemmeiza 9 x Gemmeiza 11) under drought stress condition, indicating the importance of these crosses in wheat breeding programs for improving number of spikelets/spike.

Under normal irrigation and drought stress environments, the local wheat cultivars Misr 1 and Gemmeiza 9 as well as their $F_{1}$ crosses (Misr 1 x Gemmeiza 9) exhibited the longest spike. Hereby, these genotypes could be considered as the promising ones in wheat breeding programs aiming to improve spike length. The above results indicate that genes controlling spike length are transmitted from the parents to the progeny.

In continuous and as shown in Table 5, wheat parental genotypes Line 2, Gemmeiza 9 and Gemmeiza 11 and their $F_{1}$ crosses (Gemmeiza 9 x Gemmeiza 11) had high mean values for spike density under normal irrigation and drought stress conditions. Therefore, these genotypes can be used through wheat breeding programs to improve spike density.

For number of spikes/plant, number of grains/spike and 1000-grain weight, data presented in Table 5 show that the local wheat cultivars Gemmeiza 9 and Misr 1 as well as their $F_{1}$ cross (Misr 1 x Gemmeiza 9) gave the highest mean values of these characters among the studied wheat genotypes under both environments. These results indicate that genes controlling number of spikes/plant, number of grains/spike and 1000-grain weight were transmitted from the parents to the $\mathrm{F}_{1}$ progeny. This means that these genotypes could be used for selecting new recombinants characterized by great number of spikes/plant, number of grains/spike and 1000-grain weight.

The mean performance of grain yield/plant (Table 5), indicated that the local cultivars, Misr 1 and Gemmeiza 9 as well as their $F_{1}$ cross (Misr 1 x Gemmeiza 9) exhibited the highest productivity under both environments. This result suggests that these genotypes were more tolerant to drought stress. On the other hand, the parental wheat genotypes Line 1 and Line 2 and the $F_{1}$ crosses (Line $1 \times$ Mis 1 ), (Line 1 $x$ Line 2) and (Line $2 x$ Gemmeiza 9) exhibited the lowest productivity under both normal irrigation and drought stress environments, therefore, these genotypes were more sensitive to drought stress. 


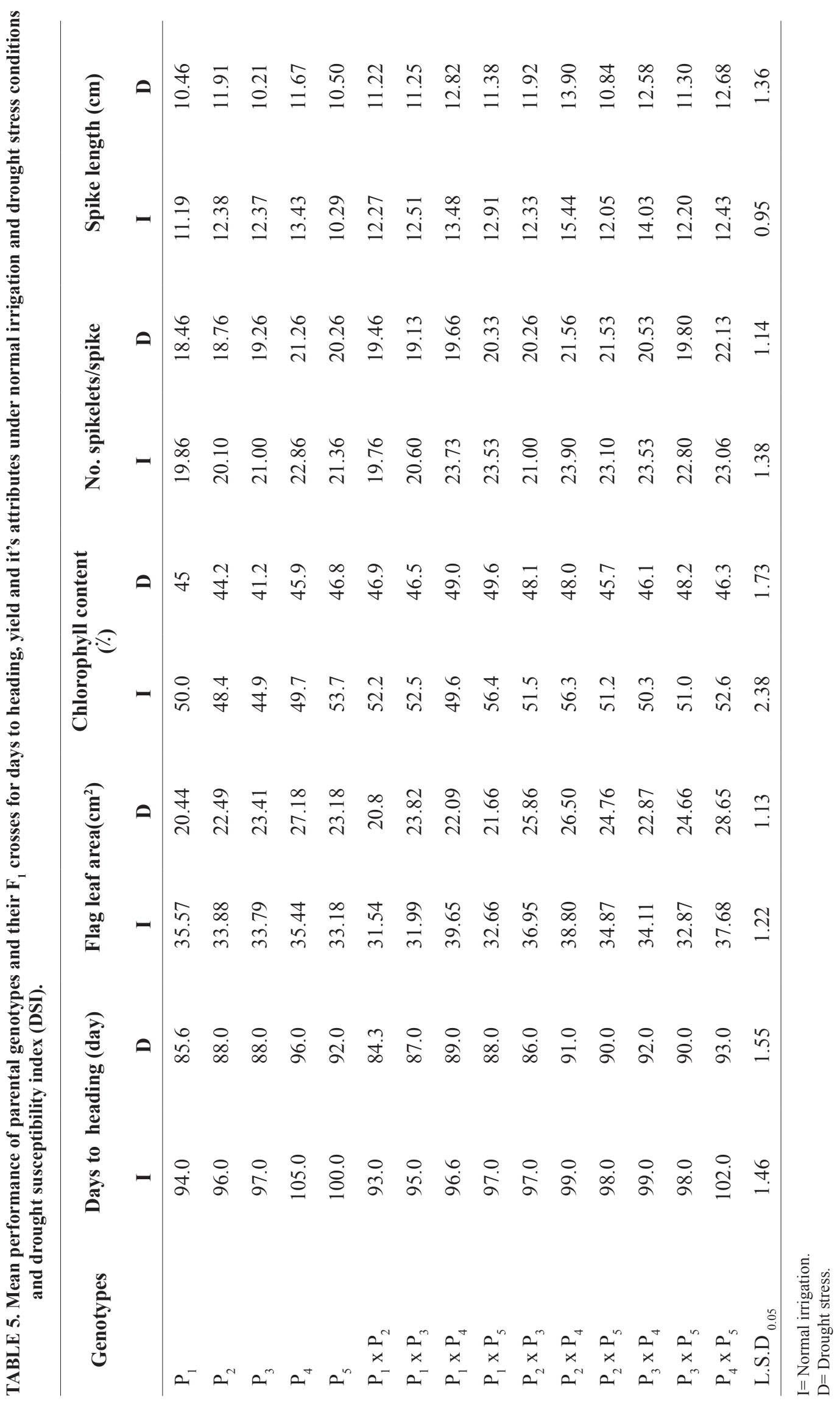




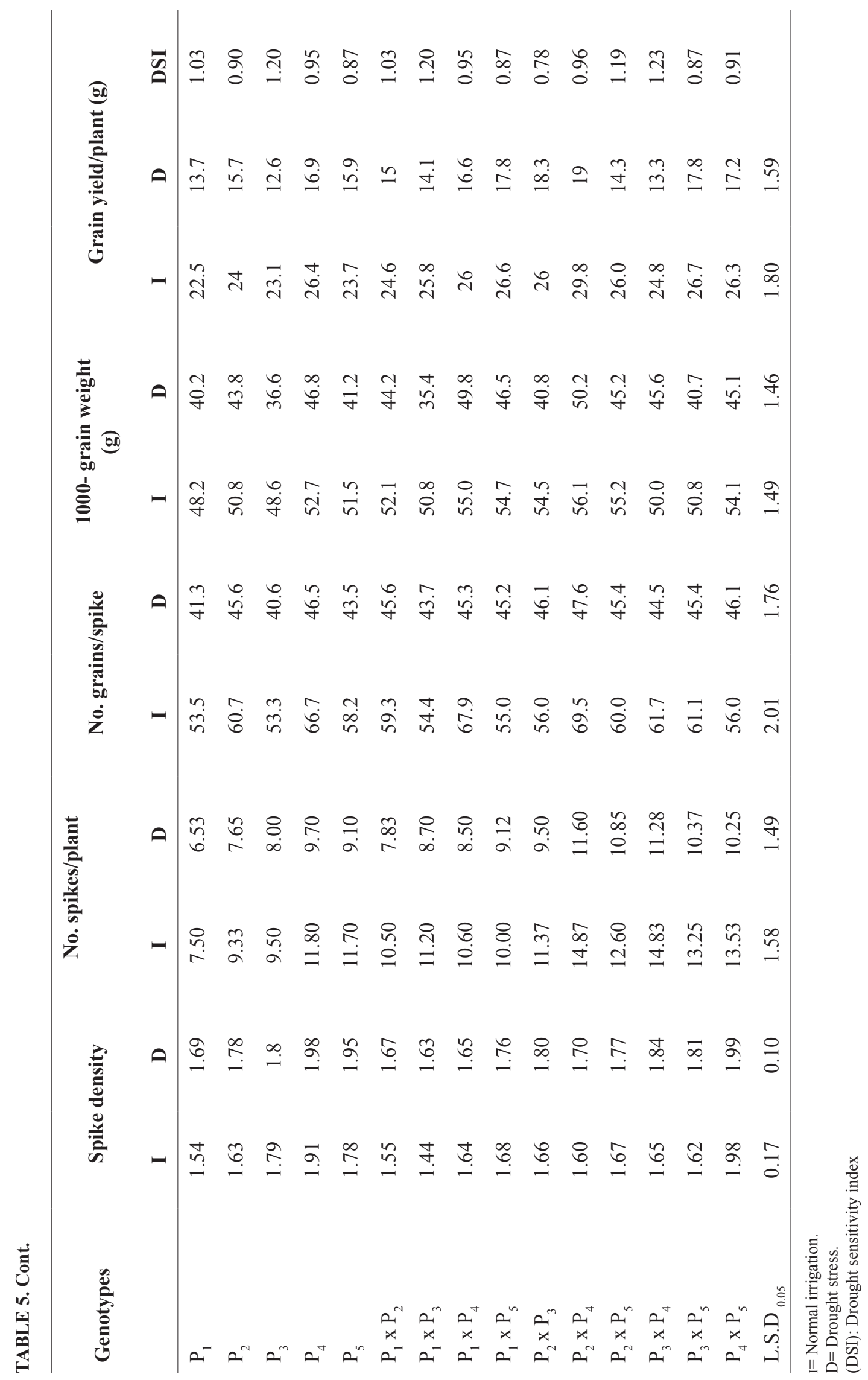

Egypt. J. Agron. Vol. 39, No.3 (2017) 


\section{Drought sensitivity index (DSI)}

The parental wheat cultivar Gemmeiza 11 and $\mathrm{F}_{1}$ crosses (Line 1x Gemmeiza 11), (Misr 1 x Line 2) and (Gemmeiza 9 x Gemmeiza 11) showed DSI values less than unity. Thus, these genotypes were considered as more tolerant to drought stress as regards to their grain yield/ plant. Moreover, parental wheat cultivars Misr 1 and Gemmeiza 9 and $\mathrm{F}_{1}$ crosses (Line $1 \mathrm{x}$ Gemmeiza 9) and (Misr 1 x Gemmeiza 9) had DSI values near one, so these genotypes were considered as moderate tolerant to drought stress. Otherwise, Line 1 and Line 2 and $F_{1}$ crosses (Line 1 x Misr 1), (Line 1 x Line 2), (Misr 1 x Gemmeiza 11) and (Line $2 \mathrm{x}$ Gemmeiza 9) had DSI values more than 1.0, hence these genotypes were sensitive to drought stress. Similar results were obtained by Gunesa et al. (2008) and Kilic \& Yagbasanlar (2010) as well as Ali \& EL-Sadek (2016), they notes a wide range of response to drought tolerance in wheat genotypes.

\section{General and specific combining ability}

General combining ability effects (gi) for days to heading are given in Table 6 . The local wheat cultivar Misr 1 and the exotic one Line 1 under normal irrigation as well as Line 2 under drought stress environment exhibited negative and significant GCA effects, revealing that these genotypes could be considered as excellent combiners for developing earliness genotypes. The wheat cultivar Gemmeiza 11 showed positive and significant GCA effects for chlorophyll content under normal irrigation condition. While, negative and significant GCA effects were obtained by Line 2 under drought stress condition. Furthermore, the wheat cultivar Gemmeiza 9 was the best combiners for flag leaf area, number of spikelets/spike, spike length, spike density, number of spikes/spike, number of grains/spike, 1000-grain weight and grain yield/plant as they exhibited positive and highly significant GCA effects for these characters under both environments, therefore could be considered as best combiners for these characters.

Regarding SCA effects for days to heading Table 6, negative and significant SCA effects were obtained from the cross combinations (Line 1 x Gemmeiza 9) under normal irrigation condition. Whereas, insignificant effects were attained by the all cross combinations under drought stress environment.
Estimates of SCA effects are presented in Table 6. Significant positive SCA effects were attained by the cross combinations (Line $1 \mathrm{x}$ Gemmeiza 9) and (Gemmeiza 9 x Gemmeiza 11) under normal irrigation cnodition, (Misr 1 $\mathrm{x}$ line 2) and (Misr $1 \mathrm{x}$ Gemmeiza 9) under two environments as well as (Line $1 \mathrm{x}$ Line 2 ) and (Gemmeiza 9 x Gemmeiza 11) under drought stress environment for flag leaf area.

Positive significant SCA effects for chlorophyll content (Table 6) in the cross combinations (Line 1 x Line 2) and (Misr 1 x Gemmeiza 9) under normal irrigation condition, (Line 1 x Gemmeiza 11) under both two environments as well as (Line $1 \mathrm{x}$ Gemmeiza 9), (Misr $2 \mathrm{x}$ Line 2) and (Line $2 \mathrm{x}$ Gemmeiza 11) under drought stress condition.

Regarding SCA effects for number of spikelets/spike (Table 6), positive significant effect under normal irrigation was detected by the one cross out of $10 \mathrm{~F}_{1}$ 's crosses (Line $1 \mathrm{x}$ Gemmeiza 11). While, insignificant effects under drought stress were detected by the all cross combinations.

Results in Table 6 show that SCA effects for spike length, revealed positive and significant towards long spike in the cross (Misr 1 x Gemmeiza 9) under two environments, (Line 1 x Gemmeiza 11) under normal irrigation condition. On the other hand, insignificant effects were registered by the all cross combinations under drought stress environment. The above mentioned crosses are classified as good combiner for this character. Positive and significant SCA effects were recorded by El-Moselhy (2009), Sedek (2009) and Rizkalla et al. (2012).

The SCA effects (Table 6) indicated negative and significant SCA effects for spike density in the two cross combinations (Line 1 x Gemmeiza 9) and (Misr 1 x Gemmeiza 9) under drought stress environment. Otherwise, all crosses had non-significant SCA effects under normal irrigation environment.

The SCA effects (Table 6) revealed positive significant SCA effects for number of spikes/ plant in the two out $10 \mathrm{~F}_{1}$ 's crosses i.e. (Misr 1 x Gemeneiza 9) under two environments and (Line $2 \times$ Gemmeiza 9) under normal irrigation condition. 


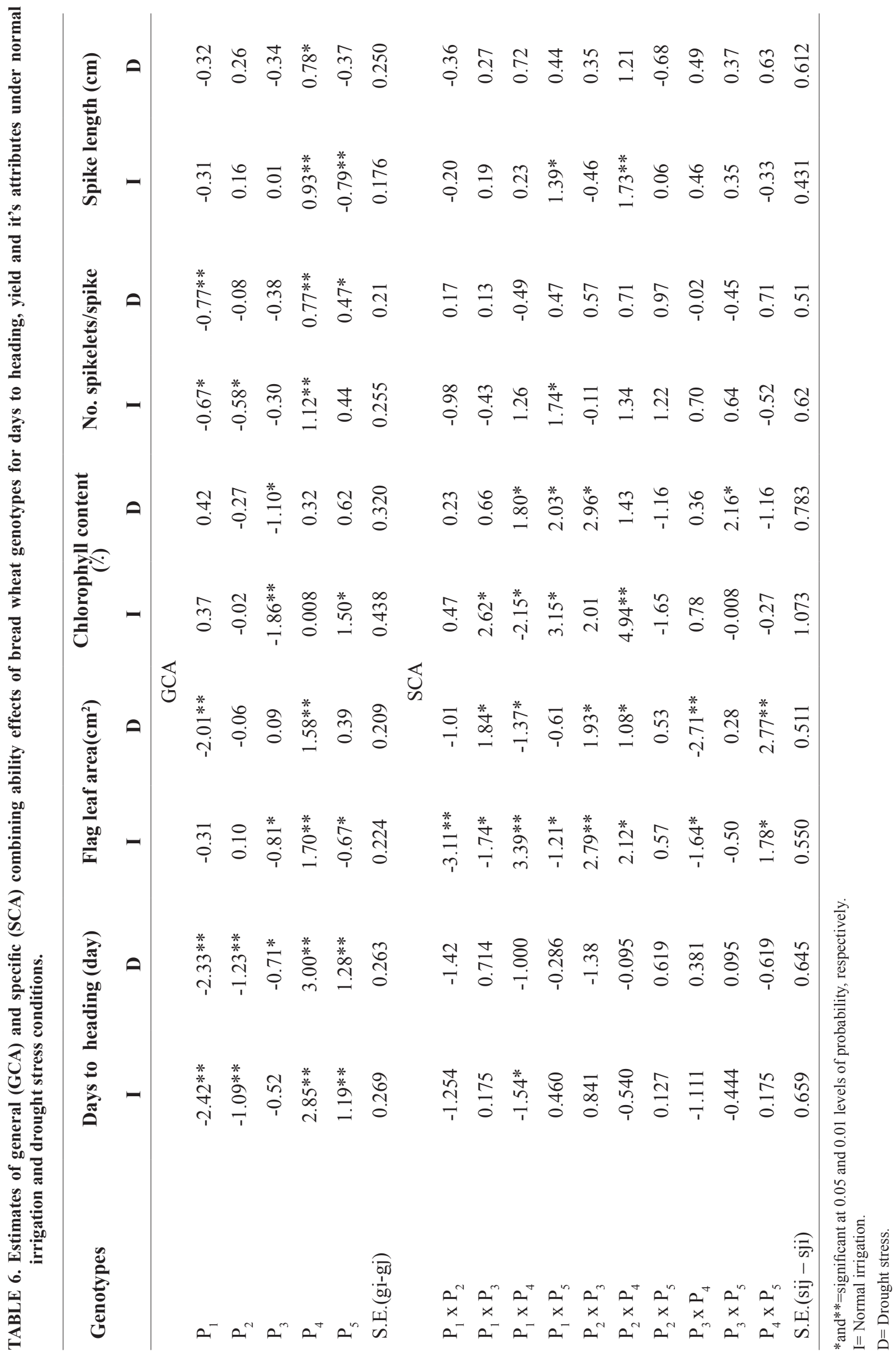

Egypt. J. Agron. Vol. 39, No.3 (2017) 


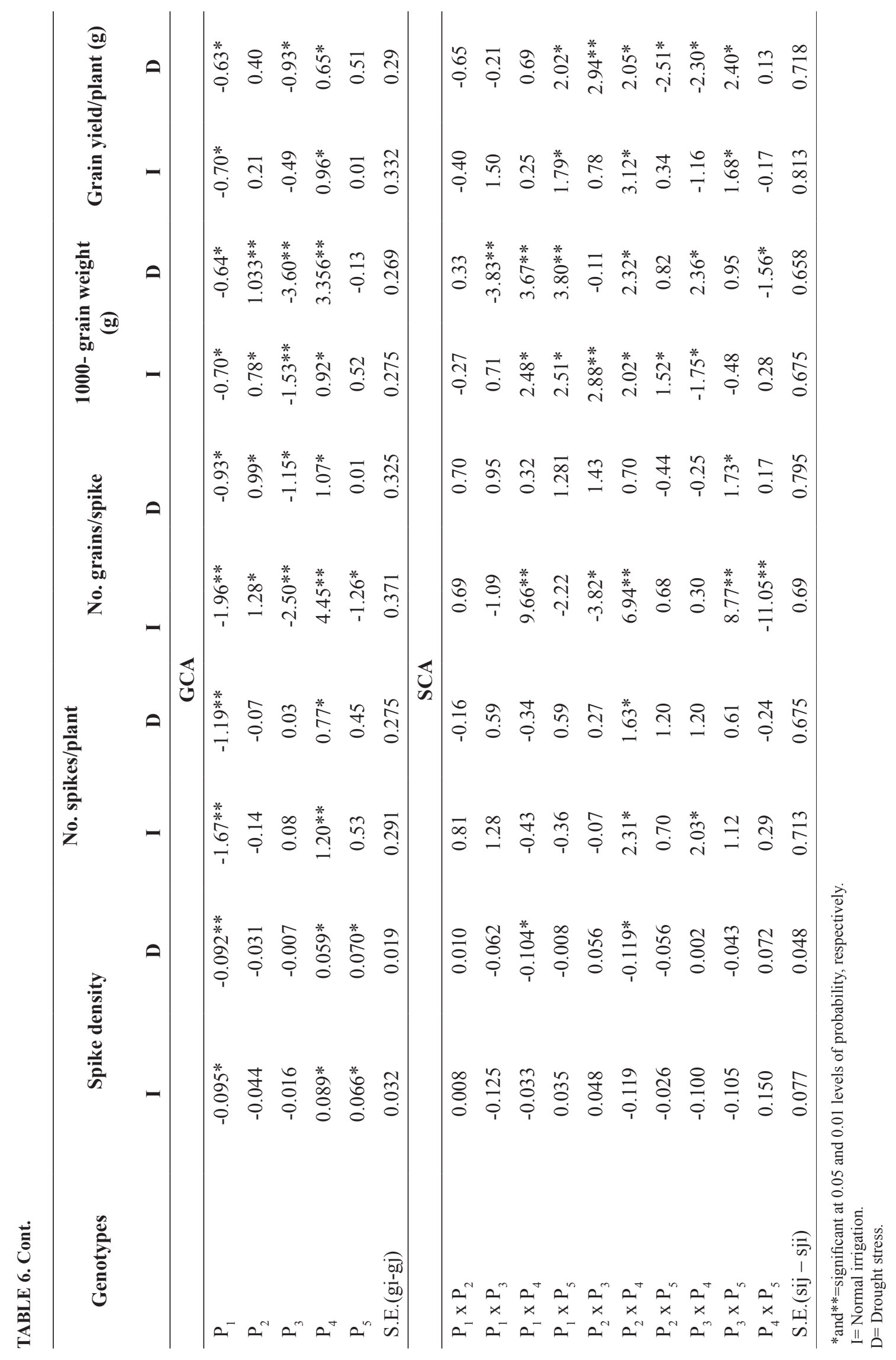

Egypt. J. Agron. Vol. 39, No.3 (2017) 
Estimation of SCA effects for number of grains/spike (Table 6) revealed positive and significant SCA effects for the three cross combinations (Line $1 \times$ Gemmeiza 9) and (Misr $1 \times$ Gemmeiza 9) as well as (Line $2 \times$ Gemmeiza 11) under normal irrigation and drought stress environments. Hereby, these crosses are considered the promising ones for improving number of grains/spike. Positive and significant SCA effects for 1000-grain weight were registered by the cross combinations (Line $1 \mathrm{x}$ Gemmeiza 9), (Line $1 \times$ Gemmeiza 11) and (Misr $1 \times$ Gemmeiza 9) under two environments, (Msr $1 \times$ Line 2) and (Misr $1 \times$ Gemmeiza 11) under normal irrigation as well as (Line $2 \mathrm{x}$ Gemmeiza 9) under drought stress environment. These crosses could be employed in breeding program for improving this character in bread wheat. Similar results were recorded by El-Moselhy (2009), Sedek (2009) and Rizkalla et al.(2012).

For grain yield/plant, estimates of SCA effects (Table 6) were positive and significant for the cross combinations (Line $1 \times$ Gemmeiza 11), (Misr 1 x Gemmeiza 9) and (Line 2 x Gemmeiza 11) under two environments as well as (Misr 1 $x$ Line 2) under drought stress environment. In general, the above crosses seemed to be good $\mathrm{F}_{1}$ cross combinations for increasing wheat grain yield.

\section{Mode of gene action}

Estimates of the genetic components of variance and their derived parameters are given in Table 7. The results indicated that additive component (D) was significant for days to heading under two environments, number of grains/ spike under normal irrigation as well as spike density and 1000-grain weight under drought stress environment, revealing the importance of additive gene action in the inheritance of these characters. On the other hand, the results indicated that dominance genetic components $\left(\mathrm{H}_{1}\right.$ and $\left.\mathrm{H}_{2}\right)$ were significant for flag leaf area and number of spikelets/spike under normal irrigation condition as well as spike length and grain yield/plant under drought stress environment, resulting the importance of non-additive gene action in the inheritance of these characters. Meantime, both additive (D) and dominance $\left(\mathrm{H}_{1}\right.$ and $\mathrm{H}_{2}$ ) genetic components were significant for chlorophyll content and number of spike/ plant under both normal irrigation and drought stress environments as well as spike length under normal irrigation environment, revealing the importance of both additive and dominance gene action in the genetic of these characters.

The magnitude of additive (D) genetic component was higher as compared to their corresponding dominance $\left(\mathrm{H}_{1}\right.$ and $\left.\mathrm{H}_{2}\right)$ ones, for days to heading under both environments and number of grains/spike under drought stress environment, resulting $\left(\mathrm{H}_{1} / \mathrm{D}\right)^{0.5}$ less than unity, indicating the presence of partial dominance and could be improved through individual phenotypic selection in the early generation for two characters. Similar results were obtained by AL-Nagger et al. (2007), El-Moselhy (2009) and Sedek (2009). On the other hand, the dominance components were higher in magnitude than the corresponding additive one for flag leaf area, chlorophyll content, number of spikelets/ spike, spike length, spike density, number of spikes/plant, 1000-grain weight and grain yield/ plant under both two environments as well as number of grains/spike under normal irrigation environment. The average degree of dominance was more than unity, confirming the importance of over-dominance gene action in controlling the inheritance of these characters. Suggesting, that the non-fixable gene type could be exploited efficiently through hybrid breeding method. Similar findings were reported by Akram et al. (2008), Ahmed \& Mohamed (2009), El-Moselhy (2009), Sedek (2009), Saleh (2011), Hussain et al. (2013) and Ahmad et al.(2016).

Positive and insignificant $(\mathrm{F})$ values were showed for days to heading under normal irrigation condition, number of grains/spike under drought stress environment as well as chlorophyll content and grain yield/plant under two environments, indicating more frequent of the increasing dominance alleles than the recessive ones in the parental populations, which was supported by high value of $\mathrm{KD} / \mathrm{KR}$ than unity for these characters. Otherwise, F values was found to be negative and insignificant for days to heading under drought stress environment, number of grains/spike under normal irrigation environment as well as flag leaf area, number of spikelets/spike, spike length, spike density, number of spikes/ plant and 1000-grain weight under both conditions, revealing that the values of (F) exhibited an excess of recessive alleles in the parents for these characters and it was supported by the ratio of KD/KR, which was less than unity for these characters. 


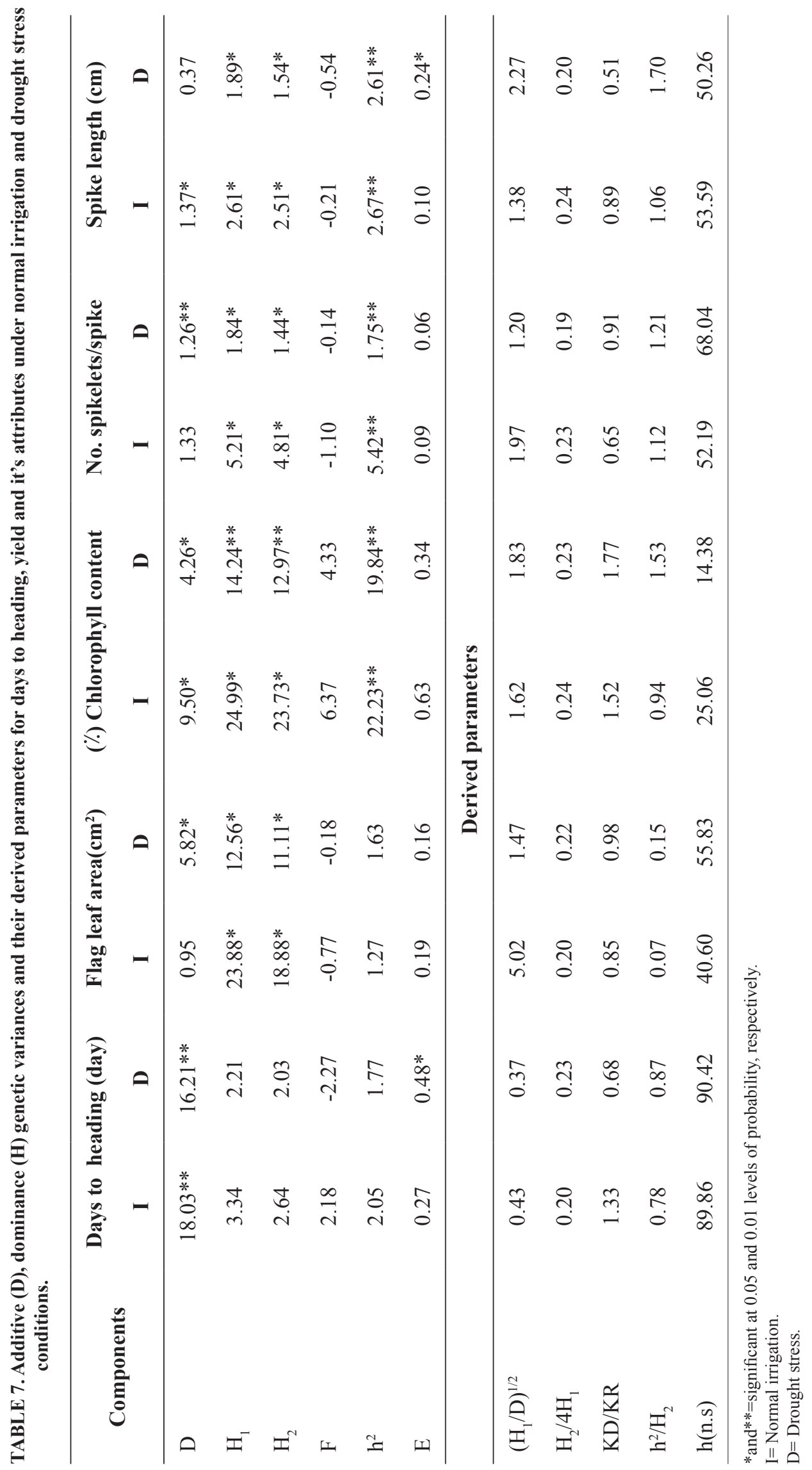

Egypt. J. Agron. Vol. 39, No.3 (2017) 


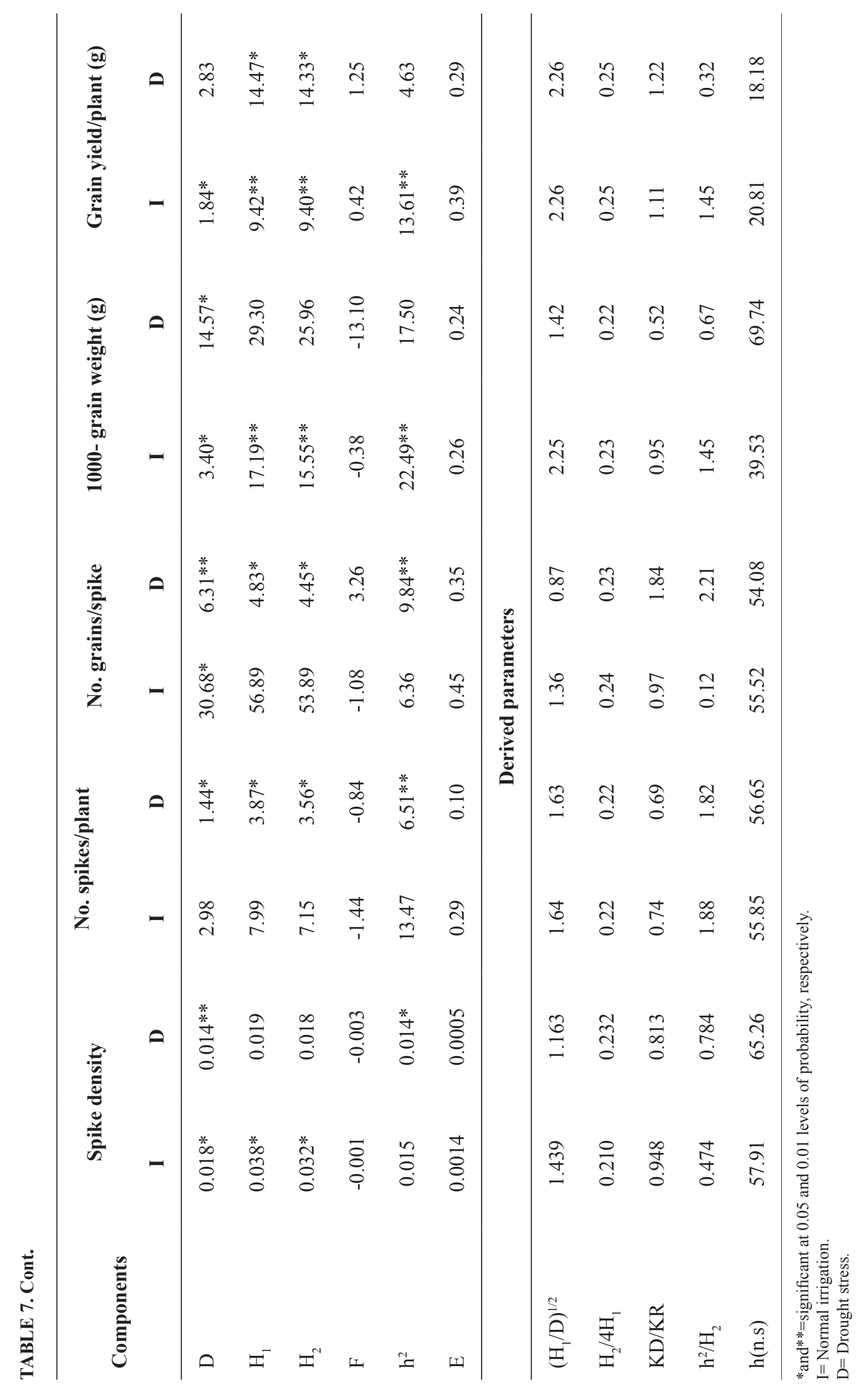

Egypt. J. Agron. Vol. 39, No.3 (2017) 
The environmental variance (E) was insignificant for all studied characters under two environments except days to heading and spike length under drought stress environment. The overall dominance effects of heterozygous loci $\left(\mathrm{h}^{2}\right)$ was positive for all studied characters under two environments emphasized that dominance was mainly attributed to heterozygous loci.

The proportion of genes with positive and negative effects in the parents as indicated by $\left(\mathrm{H}_{2} / 4 \mathrm{H}_{1}\right)$ were less than its maximum value $(0.25)$ for days to heading, flag leaf area, number of spikes/plant and 1000-grain weight under two environments, chlorophyll content, number of spikelets/spike, spike length and number of grains/spike under drought stress environment as well as spike density under normal irrigation environment, suggesting asymmetrical distribution of positive and negative alleles among the parental population for these characters. On the other hand, it was near to its maximum value $(0.25)$ for chlorophyll content, number spikelets/spike, spike density and number of grains/spike under normal irrigation environment, spike density under drought stress environment as well as grain yield/ plant under two environments, suggesting equally distribution of positive and negative alleles among the parents population for these characters.

Narrow sense heritability was high for days to heading, number of spikelets/ spike, spike length, spike density, number of spikes/plant and number of grains/spike under two environments as well as flag leaf area and 1000-grain weight under drought stress environment. Also, it was moderate for flag leaf area and 1000-grain weight under normal irrigation condition. Thus, phenotypic selection could be effective for improving both characters. In this respect, high narrow sense heritability was detected for both characters by Koumber \& El-Beially (2005), El-Marakby et al. (2007), Al-Naggar et al. ( 2007), El-Moselhy (2009), Sedek (2009) and Ahmad et al. (2016). Heritability estimates in narrow sense were low for chlorophyll content and grain yield/plant under two environments. Therefore, selection was ineffective for improving such characters in early segregating generations. In this condition, low narrow sense heritability for grain yield/plant was reported by El-Moselhy (2009), Sedek (2009) and Saleh (2011).

\section{Graphical analysis}

Relationships of $\mathrm{Wr} / \mathrm{Vr}$ for the studied traits under normal irrigation and drought stress environments are illustrated in Fig. 1 and 2, respectively. Under normal irrigation condition, the regression line cuts $\mathrm{Wr}$ axis above point of origin in days to heading, chlorophyll content, spike length, spike density and number of spikes/plant, indicating that partial dominance play a major role in the genetics of these characters. Otherwise, it cuts $\mathrm{Wr}$ axis below point of origin in flag leaf area, number of spikelets/ spike, number of grains/spike, 1000-grain weight and grain yield/plant. This indicated the presence of over-dominance gene action in the genetics of these characters. Under drought stress condition, the regression lines cut $\mathrm{Wr}$ axis above point of origin for days to heading, number of spikelets/spike, spike density, number of grains/spike and 1000-grain weight, showing that partial dominance controlling these characters through. Whereas, it cuts Wr axis below origin for flag leaf area, chlorophyll content, spike length, number of spikes/plant and grain yield/ plant, demonstrating that over-dominance gene effects are the prevailed types in the genetics of these characters. Similar results were obtained by Sami-Ulallah et al. (2010), Ahmad et al. (2011), Rabbani et al.(2011), Khodadadi et al. (2012), Abd-Allah \& Amin (2013) and Abdallah et al. (2015).

The distribution of parental genotypes along the regression lines under normal irrigation condition showed that genotype $\mathrm{P}_{3}$ possessed the most dominant genes for days to heading, flag leaf area and spike length. Also, $\mathrm{P}_{4}$ for number of spikelets/spike, $\mathrm{P}_{2}$ for spike density as well as $\mathrm{P}_{5}$ for chlorophyll content, number of spikes/plant, number of grains/spike, 1000-grain weight and grain yield/plant. On the other hand, $\mathrm{P}_{4}$ for days to heading and spike density, $\mathrm{P}_{1}$ for flag leaf area, number of spikelets/spike, number of grains/ spike and 1000-grain weight, $\mathrm{P}_{2}, \mathrm{P}_{3}$ and $\mathrm{P}_{4}$ for chlorophyll content as well as $\mathrm{P}_{2}$ for spike length, number of spikes/plant and grain yield/ plant all possessed more recessive genes. 


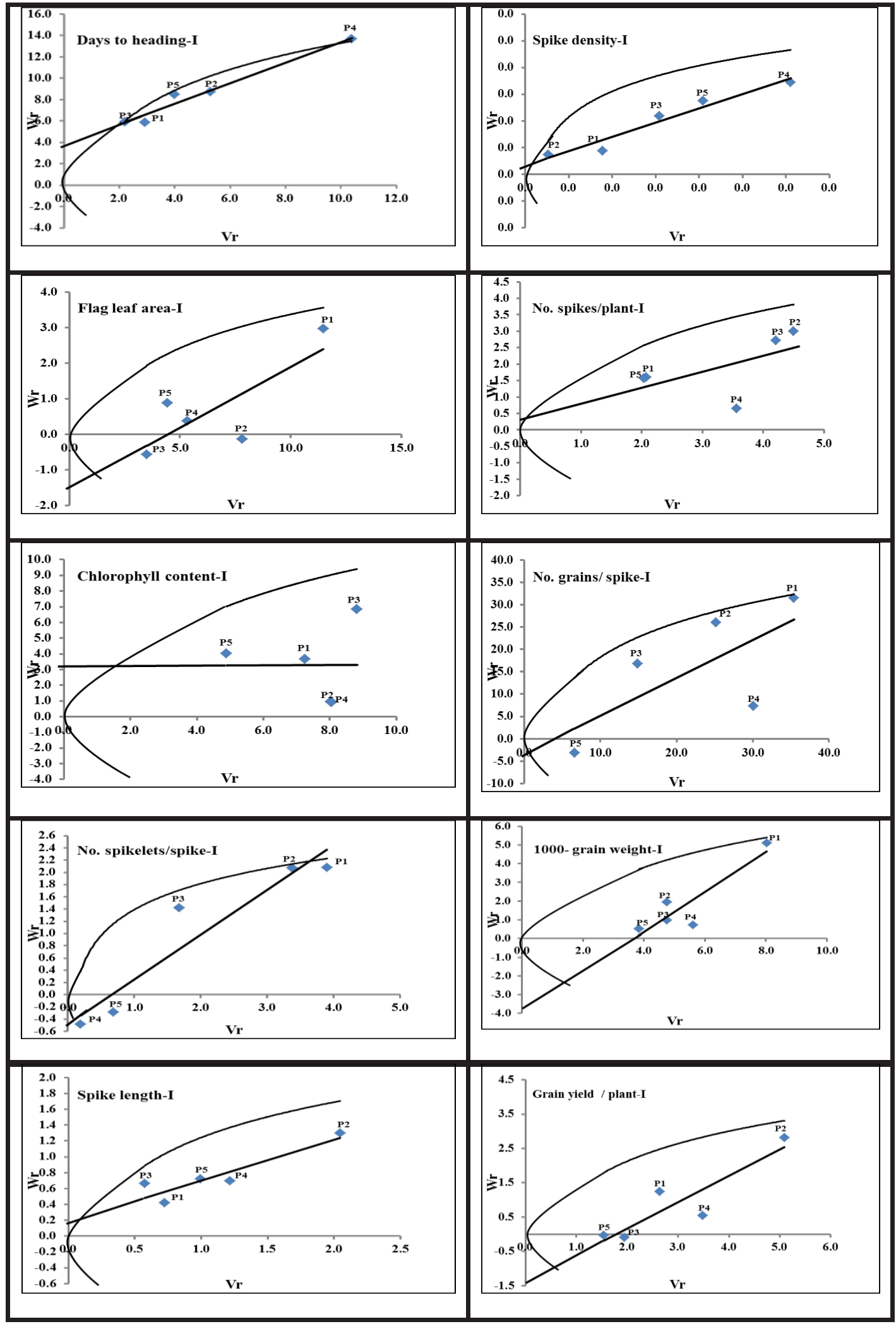

Fig. 1. Wr-Vr graph for different agronomic traits of parental wheat genotypes under normal irrigation condition in growing season 2015/2016. 


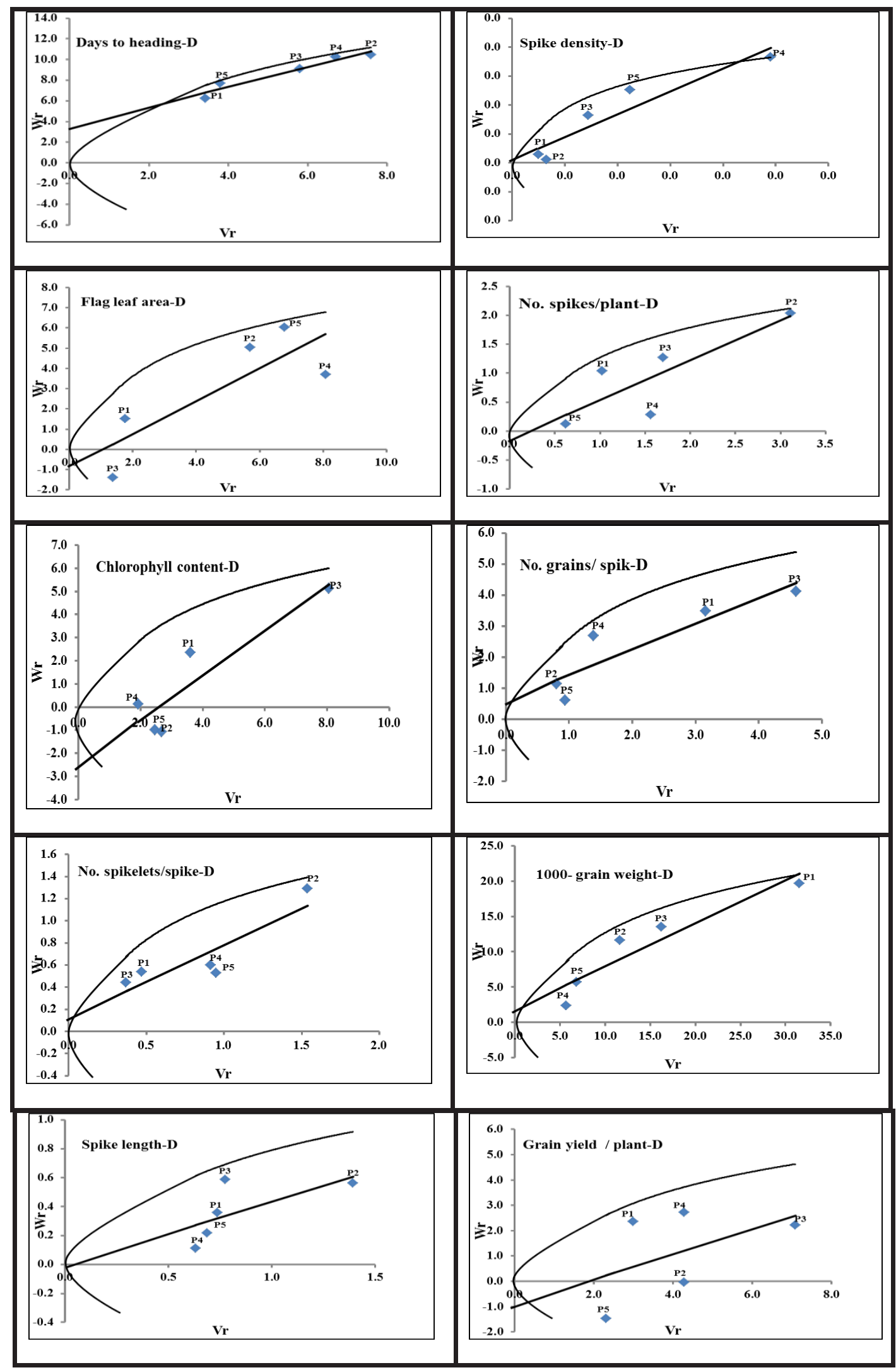

Fig. 2. Wr-Vr graph for different agronomic traits of parental wheat genotypes under drought stress condition in growing season 2015/2016. 
Under drought stress condition, distribution of parental genotypes along the regression line showed that $\mathrm{P}_{1}$ for days to heading and spike density, $\mathrm{P}_{3}$ and $\mathrm{P}_{1}$ for flag leaf area and number of spikelets/spike, $\mathrm{P}_{4}$ and $\mathrm{P}_{5}$ for chlorophyll content, spike length and 1000-grain weight, $\mathrm{P}_{2}$ and $\mathrm{P}_{5}$ for number of grains/spike as well as $\mathrm{P}_{5}$ and $\mathrm{P}_{1}$ for number of spikes/plant and grain yield/plant possessed the most dominant genes for these characters. While, $\mathrm{P}_{2}$ for days to heading, number of spikelets/spike, spike length and number of spikes/plant, $\mathrm{P}_{4}$ for flag leaf area and spike density, $\mathrm{P}_{3}$ for chlorophyll content, number of grains/spike and grain yield/plant as well as $\mathrm{P}_{1}$ for 1000 -grain weight possessed the most recessive genes for these characters.

\section{Conclusion}

The analysis of data indicated significant differences among genotypes for all studied characters. The local wheat cultivars Misr 1 and Gemmeiza 9 as well as their respective cross (Misr 1 X Gemmeiza 9) were highest values for yield and its attributes under normal irrigation and drought stress conditions. The genetic analysis with $\mathrm{Wr} / \mathrm{Vr}$ graphs indicated that days to heading are controlled by additive type of gene action, so phenotypic selection could be effective for improving days to heading. While, grain yield/plant appeared to be controlled by over-dominance type of gene action. Thus, delayed selection in segregation generation should be preferred for mentioned this character.

Acknowledgements: The authors thank Dr. Hassan A. Awaad for his valuable reviewing the manuscript.

\section{Reference}

Abdallah, E., Ali, M.M.A., Yasin, M.A.T. and Salem, A.H. (2015) Combining ability and mode of gene action for earliness, yield and some yield attributes of bread wheat (Triticum aestivum L.) genotypes grown on different sowing dates. Zagazig J. Agric. Res. 42(2), 215-235.

Abd-Allah, S.M.H. and Amin, I.A. (2013) Genotypic differences for heat tolerance traits in bread wheat using five parameters genetic model. Alex. J.Agric. Res. 58(2), 83-96.

Ahmad, I., Mahmood, N., Khaliq, I. and Khan, N. (2016) Genetic analysis for five important morphological attributes in wheat (Triticum aestivum L.). The Journal of Animal \& Plant Sciences, 26(3), 725-730.

Ahmed, M.S.H. and Mohamed, S.M.S. (2009) Genetic analysis of yield and its components in diallel crosses of bread wheat (Triticum aestivum L.) under two sowing dates. $6^{\text {th }}$ International Plant Breading Conference, Ismallia. Egypt. Abst. p. 8.

Ahmad, F., Khan, S. , Abdul Latif, H. Khan, Khan, A. and Nawaz, A. (2011) Genetics of yield and related traits in bread wheat over different planting dates using diallel analysis. Afr. J. Agric. Res. 6(6), 15641571 .

Akram, Z., Ajmal, S., Muni, M. and Shabir, G. (2008) Genetic determination of yield related attributes in bread wheat. Sarhad J. Agric. 24(3), 431-438.

Ali, M.B. and EL-Sadek, A.N. (2016) Evaluation of drought tolerance indices for wheat (Triticum aestivum L.) under irrigation and rainfed conditions. Communications in Biometry and Crop Science, 11(1), 77-89.

Al-Naggar, A.M., Moustafa, M.A., Atta, M.M.M. and Shehab Eldeen, M.T. (2007) Gene action of earliness and grain filling in bread wheat under two irrigation regimes. Egypt. J. Plant Bread, 11(3), 279-297.

Anonymous (2016) Wheat production and consumption, Economic Affairs Sector. ARC, Giza, Egypt.

Badieh, M.M.S., Farshadfar, E., Haghparast, R., Rajabi, R. and Zarei, L. (2012) Evaluation of gene action of some fraito contributing in drought tolerance in bread wheat utilizing diallel analysis. Annals of Biol. Res. 3(7), 3591-3596.

Bindraban, P.S., Sayre, K.D. and Solis-Moya, E. (1998) Identifying factors that determine kernel number in wheat. Field Crops Res. 58, 223-234.

El-Marakby, A.M., Mohamed, A.A., Tolba, A.M. and Saleh, S.H. (2007) Nature of gene action in the inheritance of earliness, grain yield and grain quality traits in diallel crosses of bread wheat under different environments. Egypt. J. Plant Breed, 11(1), 75-100.

El-Moselhy, O.M.A. (2009) Diallel analysis of earliness characters, yield and yield components in bread wheat (Triticum aestivum L.). M.Sc. Thesis, Agron. Dept., Fac. Agric., Zagazig Univ., Egypt.

EL-Shamarka, S.H.A., Abo shereif, M.A., Darwesh, I.H. 
Gaafar, N.A. and EL-fiki, H.H. (2009)Combining ability for earliness, yield and yield components traits in wheat. Minufiya J. Agric. Res. 34(1), 57-76.

Fisher, R.A. and Maurer, R. (1978) Drought resistance in spring wheat cultivars. I. Grain yield responses. Aust. J. Agri. Res. 30, 801.

Golparvar, A.R., Mottaghi, S. and Lotfifar, O. (2011) Diallel analysis of grain yield and its components in bread wheat genotypes under drought stress condition. Plant. Prod. Tech. 11(1), 51-60.

Griffing, J.B. (1956) Concept of general and specific combining ability in relation to diallel crossing system. Australian J. Biol. Sci. 9, 463-493.

Gunesa, A., Inala, A., Adakb, M.S., Bagcia, E.G., Ciceka, N. and Eraslana, F. (2008) Effect of drought stress implemented at pre- or post-anthesis stage on some physiological parameters as screening criteria in chickpea cultivars. Russian Journal of Plant Physiology, 55(1), 59-67.

Hamada, A.A. and EL-Beially, E.M.A. (2003) Assessment of some breeding parameters for yield and its attributes in bread wheat (Triticum aestivum L.). Egypt .J. Appl. Sci. 18(12), 159-176.

Hayman, B.I. (1954a) The theory and analysis of diallel crosses. Genetics, 39,789-809.

Hayman, B.I. (1954b) The analysis of variance of diallel tables. Biometics, 10, 235-244.

Hussain, M.A.,Askandar, H.S. and Hassan, Z.A. (2013) Selecting high yielding wheat hybrids from a restricted factorial mating design. Sarhad J. Agric. 29(2), 173-179.

Inamullah, Habib-Ahmed, Fadi-Mohammad, Sirajud-Din., Ghulam-Hassan and Bahmani-Gul (2006) Diallel analysis of the inheritance pattern of agronomic traits of bread wheat. Pakistant J. Botany, 38(4), 1169-1175.

Jinks, J.L. (1954) The analyses of continuous variation in a diallel crosses of (Nieotiana rustica L.) varieties. Genetics, 39, 767-788.

Khamssi, N.N. (2012) Selection criteria for improving grain yield of wheat under rain fed and irrigated conditions. Int. J. Recent Scientific Res. 3(6), 489-495.

Khodadadi, E., Aharizad, S. and Sabzi, M. (2012) Studding the genetic control of the bread quality related traits of wheat using Hayman graphical method. An. Biol. Res. 3(12), 5446-5449.
Kilic, H. and Yagbasanlar, T. (2010) The effect of drought stress on grain yield, yield components and some quality traits of durum wheat (Triticum turgidum ssp. durum) cultivars. Not. Bot. Hort. Agrobot. Cluj. 38(1), 164-170.

Koumber, R.M. and EL-Beially, M.A. (2005) Genetic analysis for yield and its attributes in bread wheat. J. Agric. Sci. Mansoura Univ. 30(4), 1827-1838.

Mather, K. and Jinks, J.L. (1971) "Biometrical Genetics" $2^{\text {nd }}$ ed. Chapman and Hall Ltd. London.

Mather, K. and Jinks, J.L. (1982) "Biometrical Gentics" $3^{\text {rd }}$ ed. Chapman and Hall Ltd. London.

Muhammad-Uzair, Ali, Z., Mahmood, T., Karim, I., Akram, U., Mahmood, N., Saeed, T. and Kalsoom, R. (2016) Genetic basis of some yield related traits in wheat (Triticum aestivum L.) under drought conditions. Imperial Journal of Interdisciplinary Research, 2(11), 2454-1362.

Parchin, R.A., Najaphy, A., Farshadfar, E. and Hokmalipour, S. (2011) Evaluation of wheat genotypes under drought stress based on phonological traits. Int. J. Agric. Crop Sci. 3(1), 12-19.

Rabbani, G., Mahmood, A., Shabbir, A., Shah, N. and Naeem-uddin (2011) Gene action in some yield attributes of bread wheat under two water regimes. Pak. J. Bot. 43(2), 1141-1156.

Rizkalla, A.A.B., Hussien, A., Al-Ansary, M.F., Nasseef, J.E. and Hussein, M.H.A. (2012) Combining ability and heterosis relative to RAPD marker in cultivated and newly hexaploid wheat varieties. Aust. J. Basic Appl. Sci. 6(5), 215-224.

Saleh, S.H. (2011) Genetic parameters of diallel crosses in bread wheat under normal irrigation and drought conditions. Egypt. J. Plant Breed. 15(3), 85-107.

Salahi, S., Golami, S., Rahmati, A. and Golparvar, A.R. (2014) Combining ability of biological yield and harvestindex in diallel cross of wheat cultivars under drought and non- drought stress conditions. Agric. Conspec. Sci. 79(4), 221-226.

Sami-Ulallah, Khan, A.S., Raza, A. and Sadique, S. (2010) Gene action analysis of yield and yield related traits in spring wheat (Triticum aestivum L.). Int. J. Agric. Biol. 12(1),1814-9596.

Sedek, N.K. (2009) Effect of diallel size on the estimation of some genetic parameters in bread 
wheat (Triticum aestivum L.). M.Sc. Thesis, Agron. Dept., Fac. Agric., Zagazig Univ., Egypt.

Steel, R.G.D., Torrie, J.H. and Diekey, D.A. (1997) "Principles and Procedures of Statistics. A Biometrical Approach" $3^{\text {rd }}$ ed McGraw-Hill Book Co. New York.

Swelam, D.A., Ali, M.A., Hassan, A.M. and Salem, A.H. (2014) Selection criteria for improving wheat grain yield under normal irrigation and drought stress environments. Zagazig J. Agric. Res. 41(4), 695-704.

Tsegaye, D., Dessalagn, T., Dessalagn, Y. and Share, G. (2012) Genetic variability, correlation and path analysis in durum wheat germplasm (Triticum durum Desf). Agric. Res. and Reviews, 1(4), 107-112.

(Received 25 / 7/ 2017; accepted 8 / 11/2017)

التحليل الوراثى للمحصول ومساهماتة فى قمح الخبز تحث ظروف الرى العادى واجهاد

أجريت هذه الدر اسة بالمزر عة التجريبية بكلية الزر اعة جامعة الزقازيق خلال الموسمين الثتويين 2014/2015

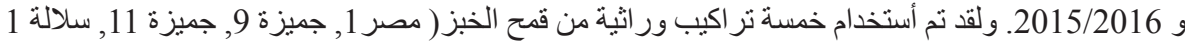

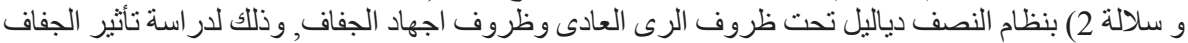

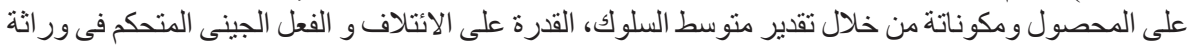

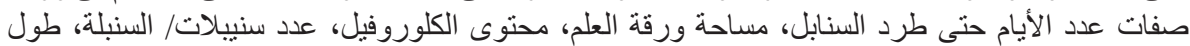

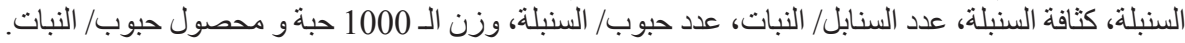

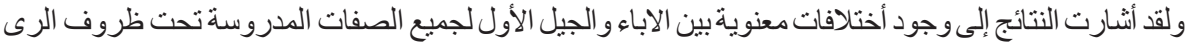

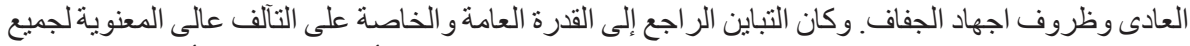

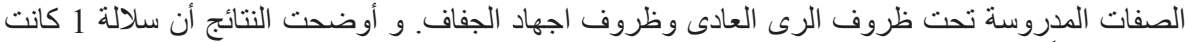

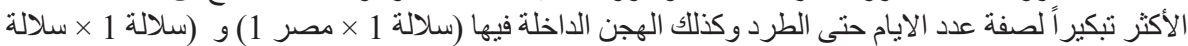

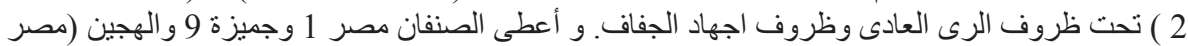

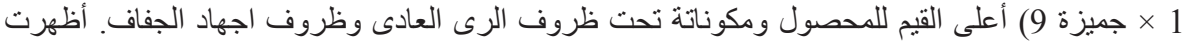

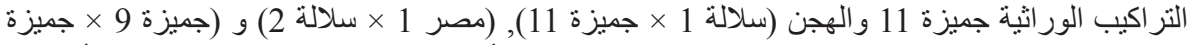

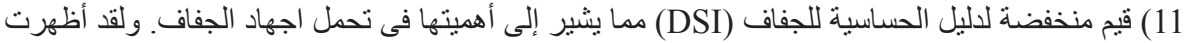

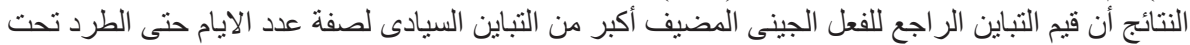

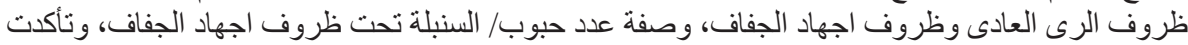

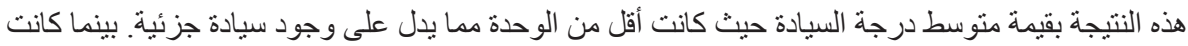

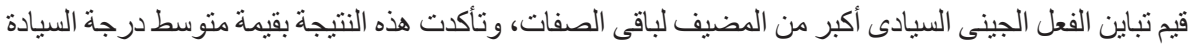

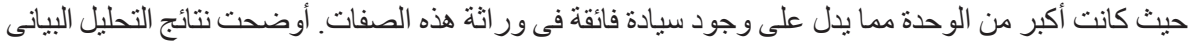

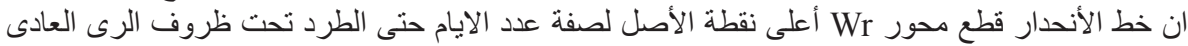

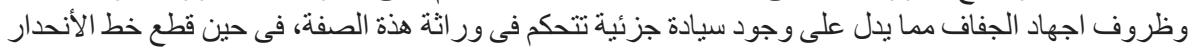

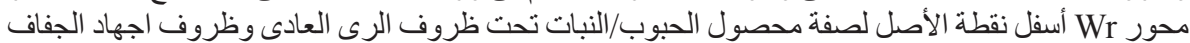

مما يدل على وجود سيادة فائقة فى ور اثنة هذه الصفة لفئ. 